\title{
RADICAI THACIFR
}

A SOCIALIST, FEMINIST, AND ANTI-RACIST JOURNAL ON THE THEORY AND PRACTICE OF TEACHING

Experiential Learning in Ghana:

Decentering the White Voice

by Robin P. Chapdelaine and Megan Toomer

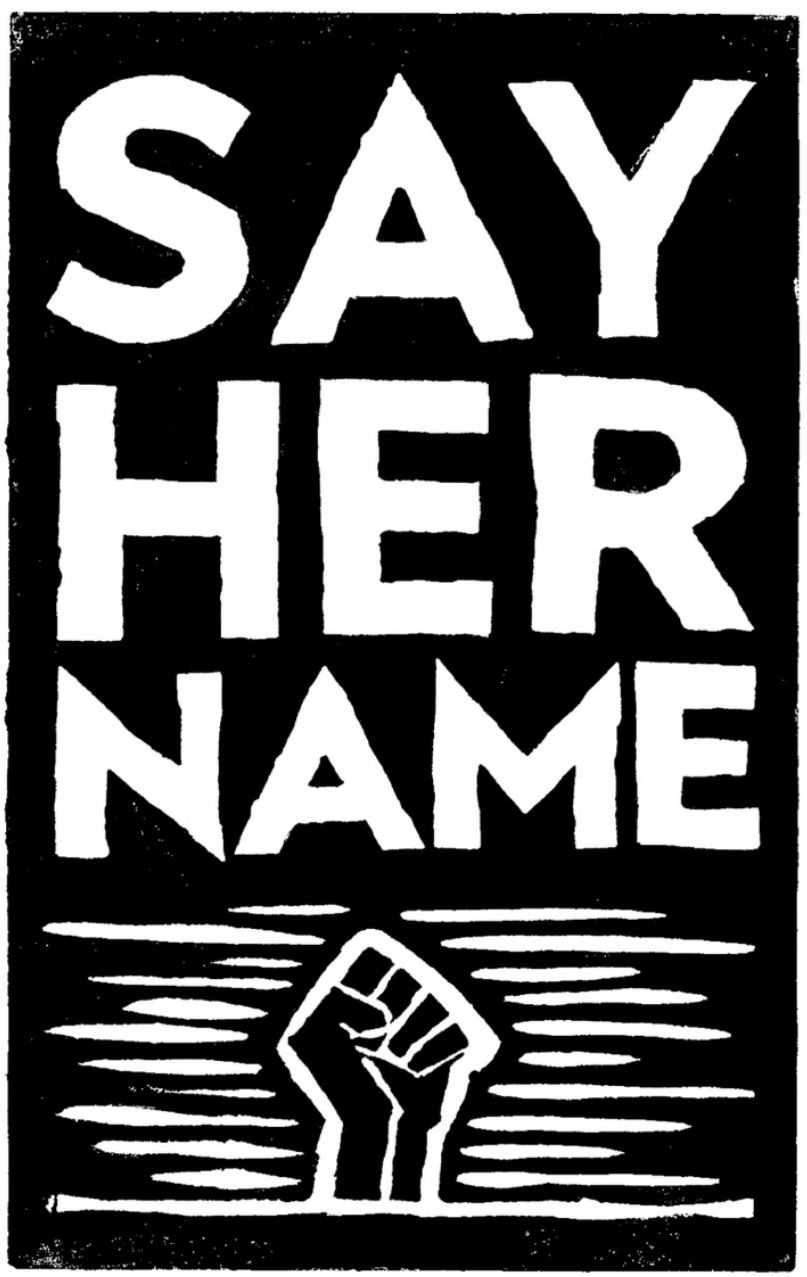

"SAY HER NAME" BY DESIREE ASPIRAS VIA JUST SEEDS 
$\mathrm{T}$ his article is co-authored by an Afro-Latina Assistant Professor and a Black woman who is a former undergraduate student at Duquesne University and current Emory Law student. We examine how undergraduate students from Duquesne University, a predominantly white liberal arts institution, experienced a course on Precolonial Africa during a 2019 summer study abroad, "Maymester," in Ghana.1 The outcomes provided and analyzed in this article are a comprisal of the co-author's personal narrative, formal university Student Evaluation Survey (SES) responses, and anonymous online reflection survey responses created by the faculty member and the former student co-author. The SES responses rendered a 7 out of 15 at a $46.67 \%$ response rate and a 12 out of 15 at a $80 \%$ response rate for the secondary survey. The student demographic included one South Asian student of color, one native of Spain who did not racially self-identify, ten white students, and three African American/Black students. (2)

The goals of this course included learning about Ghanaian history and understanding differences between precolonial indigenous modes of labor extraction and new forms of slavery that developed in Ghana and the United States as a result of the Transatlantic slave trade. White supremacy served as the foundation of the Transatlantic slave trade and the subsequent institution of chattel slavery in the U.S. (3) As such, it is not an exaggeration to say that U.S. history is rooted in the oppression of non-white populations who have experienced and continue to experience political, social, and economic disenfranchisement in addition to various forms of physical and emotional harm. This history has influenced that the way U.S. Americans view other non-white populations, especially those in the Global South.

The aim of study abroad programs often seeks to educate college students about the Global South. These programs, however, do not adequately prepare students from racially diverse backgrounds, particularly white, affluent students from the Global North, who comprise the overwhelming majority of participants, to negotiate the horrific terrors of imperialist histories with their student of color counterparts. We argue that an interracial dialogue on the terror of whiteness on Black bodies and in Black spaces, which is steeped in historical context, is challenging even when white student voices do not predominate in classroom discussions. By sharing and prioritizing Megan's account of the program, we show that when decentering white student voices, white students, while seemingly willing to listen and learn, have a limited ability to empathize with the emotional pain and raw grief felt by Black students.

This article stresses the limitations of cultural competence pedagogy as a learning outcome in light of some of the preconceived notions students held about Ghana and Africa. The limitations are also evident by virtue of particular incidents that occurred during site visits. In addition to promoting cultural competency practices, we argue that universities have a moral responsibility to introduce anti-racist pedagogy to student participants before the start of the study abroad program as a measure to discourage student behaviors that subordinate Black voices and as a way to fight white supremacist ideologies and behaviors. Students should learn about the historical legacy of structural and institutional roots of white supremacy and anti-blackness. We believe that this article can serve as an example as to how study abroad classrooms can become sites of contestation where Black voices demand attention when expressing their personal relationship to the history that is taught and the emotional pain that it provokes.

\section{Individualism and the Limitations of Cultural Competency Pedagogy}

It has been argued that U.S. American students tend to lack a global view or worldview that does not center their own temporal existence. For example, Ibram $\mathrm{X}$. Kendi explains that when he and other students scored higher than poorer students on high school standardized tests, which he describes as "one of the most effective racist policies ever devised to degrade Black minds and legally exclude Black bodies," they took "personal credit for any success." (4) It did not occur to Kendi and his classmates that there existed structural reasons for their superior academic accomplishments - mainly access to economic resources, which afforded them additional learning opportunities and tutoring. Their view was limited to what they understood according to their temporal existence in that moment. In that way, an analysis of our study abroad program demonstrates that this is also the case for white student participants as it relates to understanding the violent history of racism, slavery, and continued racial trauma. Our assessment is not positioned to be a personal criticism of students; rather, it is an acknowledgement of the consequences resulting from the lack of broader education initiatives that speak to the deep and systematic history of racism in the U.S. and globally.

During the program, students engaged the course material, Ghana, and Black Ghanaians in a manner that was reflective of their personal identity. White students had the opportunity to learn about Ghanaian history in class through lectures, role play, and class discussions and through historical site visits through the lens of white supremacy according to the limited education they received about the slave trade and chattel slavery in $\mathrm{K}-12$ schooling. Black students, however, engaged the course material, Ghana, and Black Ghanaians through a similar educational lens, but their perspectives reflected their lived experiences with white supremacy and racism rendering the histories learned in class as personal, familiar, and often painful. Their shared emotional experiences, often reflected in rage as well, reinforced what Angela Davis has acknowledged, that, "As black people, as brown people, as people of color...we know and we experience the agony of the struggle for existence each day. We are locked into that struggle." (5) It is this 'struggle' that students of color understood, reflecting upon their interpersonal challenges as they participated in each class. During roundtable classroom discussions, many students expressed that they understood that the roots of their current-day experiences were born from the legacy of racism and slavery in the U.S. In contrast, white students did not directly engage in their own complicity in white supremacy. In part, this was due to the course design, as students were not required to read material that addressed 
anti-racist pedagogy or Critical Race Theory (CRT) material. However, the deep emotional responses that were expressed by Black students and surprisingly our Ghanaian tour guide, who wept with us when discussing the horror of the slave trade, compelled many white students, as demonstrated by their own emotions, to grieve alongside us. In this way, even if they did not directly address their complicity in white supremacy, multi-racial solidarity was achieved momentarily.

The classroom is a site where anti-racism and personal complicity in white supremacy can and should be taught. For example, when we as educators employ a pedagogical approach that teaches students about white privilege and the historical trauma spurred by white supremacy, it is essential that we provide an accurate historical account of how and why racism and white supremacy exist, i.e. political, economic, and legal contexts, often referred to as Critical Race Theory. (6) George J. Sefa Dei asserts that "critical anti-racism practice must root the understanding of racism in histories of colonial oppressions, colonialisms, imperialism, and xenophobia, while further placing such discussions in contemporary global/transnational contexts, including global capitalism, and internationalization of labor and markets." (7) This type of antiracist endeavor can highlight "blind spots and structural bias." 8 Just as the Student Nonviolent Coordinating Committee (SNCC) members of the 1960 s noted that, "racial discrimination was institutionalized" and that "racial animus against African Americans [was] social in origin," contemporary educators must also historicize the legacy of racial animus. (9)

Study abroad programs can begin to do some of this work. In part, the significance of students traveling abroad is that their presuppositions about particular groups can be destabilized; opening up their understanding of 'others' gives them the opportunity to re-think personally held stereotypes about other global societies. For example, one observant student noted that,

This course taught me the history behind a lot of modern-day social phenomena. Like the hypercriminalization problem and how racism is an observation of difference taken further and developed into a very strong negative bias. It was just very eye-opening historically and socially.

While this student's race is unknown, conclusions can still be drawn about their shift in racial consciousness. If this student is white, their experience in Ghana positioned them to contend with the ways in which their whiteness has shielded them from persecution by the carceral state and informal policing from other white people. If this student is Black, their experience in Ghana has broadened and complicated their existing framework for understanding their own criminalization and that of Black people in the Global South and, perhaps, their own internalized anti-blackness. (11)

$$
12 \text { responses }
$$

The student's statement is a significant example of how the history of anti-blackness, indigenous slavery in Ghana, and chattel slavery in the U.S. seems to be largely absent in U.S. predominantly white educational institutions. Thus, intersecting history with experiential learning opportunities provokes a deeper level of analysis, leading to broader understandings about the importance of history and increases the potential for cultural competency. The American Psychological Association's definition of cultural competence is, "the ability to understand, appreciate and interact with people from cultures or belief systems different from one's own," which is an extension of cultural awareness development. Cultural awareness means developing a "selfawareness" of, one's "own cultural background" against which other cultural backgrounds are compared and differences recognized. Awareness recognizes difference, while competence pushes the individual to appreciate and interact with people from diverse backgrounds. (12) However, appreciating and learning about different cultures does not provide any material benefit as it relates to historically institutionalized practices that subordinate certain groups. For instance, in his discussion about racism in the U.S., Eduardo Bonilla-Silva argues that "whites today rely more on cultural rather biological tropes to explain blacks' position in this country." (13) Thus, being exposed to and learning about one's culture does not always result in the dismantling of racism and racist structures.

\section{Challenging Stereotypes}

When asked "Why did you choose to go on a study abroad to Ghana?" the majority of respondents indicated that their decision was based upon a previous interest in Ghana and/or the African continent.

\section{Why did you choose to go on a study abroad to Ghana?}

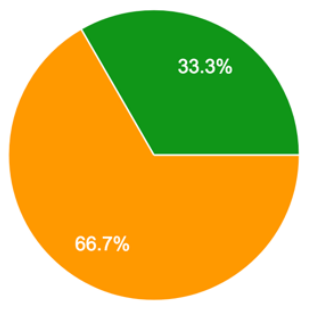

\footnotetext{
It was the shortest study abroad. It was the cheapest study abroad. I had a genuine interest in Ghana/ Africa.

It fulfilled a global diversity/African Studies/History requirement.
}

While most students expressed enthusiasm about visiting Ghana, they brought with them a host of preconceived ideas of what that experience would be like. The largest held misconception was that Ghanaians did not have access to technology. This assumption reveals the media messaging students consume in the U.S. Mainstream media generally represents Africa and its people as poor, diseased, without educational or employment opportunities, as well as lacking access to information technology and other digital tools. (14)

\section{RADICALTEACHER}




\section{What preconceived notions about Ghanaians/Africans and/or Ghana/Africa were challenged MOST during your trip? \\ 12 responses}

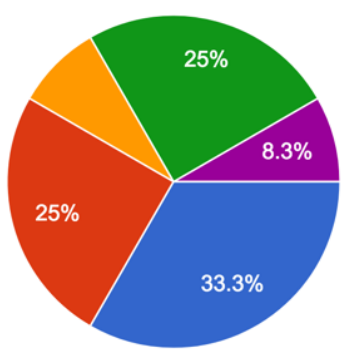

Technological advances

Food

People

Infrastructure

i didnt really have any preconceived notions

students hesitated to speak. Yet, Black students felt painfully connected to the histories and expressed raw rage, loss, and sadness about white terror. Thus, the white students were uniquely situated to listen and begin to understand why decentering the white voice in the classroom was necessary to truly appreciate the historical legacy of white supremacy.

It seemed that, in part, students may have been fearful of saying 'the wrong thing' or perhaps they understood that the emotional unpacking the Black

Media shaped students' beliefs that Africans are technologically inept. Fifty-eight percent of students responded that existing technological advances and infrastructure challenged their preconceived notions about Ghana. The idea that African countries need to bridge the "digital divide" reinforces the ideology that the West is developed and Africa is underdeveloped. (15) While social and economic issues do exist on the continent, the chance for students to 'see for themselves' offered an opportunity to become more familiar with realities on the ground and perhaps change their view of Africa at large.

\section{Considering the Emotional Toll of Interracial Dialogues}

It is impossible to predict the outcomes of any given study abroad experience. The emotional investment and responses presented in this course reflected the internal, often painful feelings that developed as the process of learning occurred. This is not surprising as emotions are an important building block to learning outcomes.16 John Dewey, American psychologist and philosopher, asserted that education is a process of preparation and "is a continuous process of growth, having as its aim at every stage an added capacity of growth." (17) It is evident that many students experienced this study abroad as meaningful yet intense and increased their cultural knowledge along the way. While some students enjoyed the open discussion component of the course, highlighting that the course held "Socratic seminar like discussions, giving everyone a chance to participate," and that those discussions assisted in the learning process, others found it more emotionally challenging. (18) As one student noted, "a lot of stuff we talked about ... involved very hard subject matter, making it even harder to get words you wanted to say out, but weren't sure they were the right things to say. It was hard to process a lot and sit there and reflect while taking in so many other things." (19) These comments show that students were not passive learners; rather, even when silent, they actively consumed the information and tried to process the emotionally difficult material. Similarly, during a discussion about an incident during a class visit to a historical site (discussed later by Megan), it was apparent that some students were engaged in was critical and important but did not necessarily know how to acknowledge it an audible manner. For instance, students had the following responses after completing the course:

That just because you read about something doesn't mean you understand it. Some things have to be lived and felt to truly know what they mean. (20)

What I learned was very important. I had never had such an involved and in-depth teaching about slavery and this was so important for me to experience. (21)

Appreciation for what I have, a deeper understanding of history relating to slavery, wider world view. (22)

Moderating these discussions was challenging; however, engaging in this type of activity should be considered as one method by which anti-racist pedagogy can begin to be taught. Daniel Paracka argues that "Global issues of race and gender, power and privilege, social justice, and sustainable development remain critically important subjects in need of greater attention, mutual accountability, and shared understanding." (23) One activity, which required students to read Trevor Getz's Abina and the Important Men (2015), allowed all students to physically engage in the active story telling of an enslaved woman named Abina and consider some of the themes Paracka has outlined. The book is a graphic history that provides the account of a "wrongfully" enslaved woman according to 1876 court records. Students chose their parts, read, and acted out the scenes accordingly, often proclaiming surprise or anger at the unjust capture and maltreatment of Abina by African, British and mixed-race men.24 Her determination to petition the court and her defiance of gendered expectations challenged student assumptions about women living in precolonial Africa-again dismantling previously held stereotypes.

\section{Benefits Outside of the Classroom}

Students have the potential to develop into globally minded citizens when there is supportive curriculum and diversity within the classroom, but it is complicated. Yolanda Moses contends that "colleges and universities" should "be places where humanistic notions of democracy and inclusive 
ways of knowing help all our graduates negotiate and thrive in an increasingly diverse society." (25) Affording students the opportunity to participate in a study abroad experience provides them with new knowledge of a given subject matter, new perspectives about people different than them, and new understandings of self that they can apply to their lives outside of the classroom. When asked, "Do study abroad experiences prepare you for the workforce? Why or why not?" students stated:

Yes, because they teach you how to interact with people from different cultures and they also teach to how to adapt to different environments. (26)

Absolutely, it allows you to throw yourself into another culture and to appreciate the differences, and to learn that just because it is different than your own doesn't mean it is wrong. That is extremely important to apply to the work force. (27)

Yes, better cultural understandings. (28)

Yes, it taught me to have cultural competency not just cultural awareness. (29)

In hindsight, the question that prompted these responses was naïve. While it is encouraging to know that most students believe that their study abroad experience will enhance their workplace encounters, the curriculum offered could have and perhaps should have delved more readily into the historical injustices suffered by non-white populations in the U.S. and globally, and how those histories created prevailing racist institutions. In other words, a more interesting question would have been, "What have you learned that will help you address and eradicate racism in the workplace?' or something to that effect.

\section{Affective Investment and the Need to Connect}

Jorge Cubillos and Thomas Ilvento argue that study abroad programs, "have the power to shape how we view ourselves, and the value we assign our own culture in relation to the culture" of those with whom students come into contact. "Moreover, they influence our disposition towards ... and our investment in" those in the destination country. (30) This is noteworthy because the process of having to physically and emotionally locate themselves in a foreign environment forces students to develop skills beyond those taught in a classroom at home. Arriving in a new place where the culture, environment, language, and even the food is different is difficult for anyone to a certain degree, but even more so for young adults, especially when they have limited experience travelling abroad. For some students, the affect they held for Ghana resulted from their personal identity and longing to understand their history as a descendant of the Africa diaspora. However, understanding their level of affect for a particular destination may shed light on the various responses. Cultural anthropologist Neriko Musha Doerr argues that "affective investment" determines the student's experience in the host country. While some students have a "high degree of affective investment, highlighted by carefully observing and copying" the residents in the host country, others have a "low degree of affective investment, instead connect[ing] with the people in the destination, playing down the difference." (31)

The tendency of descendants of the African Diaspora to seek unity by creating affinities based on identity that expands beyond national borders is one born from disenfranchisement, displacement, and white supremacy. A. Doris Banks Henries (1913-1981), former American educator and Assistant Minister of Education in Liberia once, argued that, "Every living person needs the stimulation derived from a sense of belonging. He needs to know and appreciate his past history, culture and foundations in order to have self-esteem and hope." (32) Efforts by historical figures such as Martin R. Delany, known as the "Father of Black Nationalism," W.E.B. Du Bois, Marcus Garvey, Elijah Muhammad, Martin Luther King Jr., Booker T. Washington, Malcom $X$, and many others have worked to achieve this goal. (33) Likewise, Black students' participation in the Ghana study abroad provoked new awareness and appreciation for their collective history. Therefore, it is crucial to center a Black student's experience in this article in order to understand how being born from the African diaspora shaped Black students' experiences during the program where they leaned on each other for emotional support. This article does so by incorporating the student coauthor's

account.

\section{Student Co-Author Response}

Studying abroad in Ghana was a highly anticipated moment for both myself and my classmates. We each chose to study overseas for varied reasons and participated in several significant learning experiences and challenges. As we read thought-provoking educational materials about the history of Ghana and acclimated to a new environment, we gained valuable knowledge about the pervasive impact of the Transatlantic Slave Trade and the effects of the slave trade presently. Furthermore, as students, our experiences allowed us to uniquely engage with the complexities of our identities. Traveling to Ghana further cultivated my relationship with the African diaspora and allowed my peers and me to physically experience prominent historical sites while meaningfully communicating with one another in our experiential learning class.

To further engage with the readings and academic material in our Pre-colonial African History course, we visited many historical sites. Our class first visited Elmina Dungeon and Cape Coast Dungeon. The Portuguese built Elmina Dungeon in 1482. The dungeon was initially under Portuguese rule and then transitioned to Dutch governance. (34) European actions during the Transatlantic Slave Trade littered Elmina Dungeon with violence, deprivation, and suffering. Although Elmina is no longer an active slave dungeon, stepping into the cells quickly reconnects visitors to an overwhelmingly gruesome and violent history. As I walked through the cells, I experienced a deep sense of sadness and shock due to the inhumane treatment that occurred at the site.

As a descendant of the African diaspora, I also realized that I would never receive the closure I was seeking, which fueled feelings of frustration and loss. My emotions 
intensified during and following my visit to Cape Coast Dungeon. The dungeon is three stories high and took 50 years to construct. From the outside of the site, visitors can see cannons that point toward the Atlantic Ocean. The site also sits high above the town of Elmina. (35) The details and size of the site immediately struck me as daunting and, equipped with the historical facts of Elmina Dungeon, I attempted to mentally prepare myself to receive the history of Cape Coast Dungeon. Despite my mental preparation, I could not fully grapple with the immense loss experienced at the site. Our tour guide detailed the horrific acts and punishments that occurred in the dungeon. The concrete crumbling beneath my feet from years of human excrement, blood, vomit, and remains were a cruel reminder that death and suffering were inextricably woven into the foundation. As an African American, visiting both historical locations and concurrently absorbing the details of the Transatlantic Slave Trade was incredibly difficult. I felt overwhelmed by the painful history of both places.

The exposure to historical sites while reading related historical scholarship made evident my unfamiliarity of all of the atrocities embedded in the institution of slavery, despite my ancestry, due to intentional information suppression both historically and presently by academia. Studying abroad and, specifically, walking through the historical locations added nuance to my experience within the African diaspora and prompted me to further interrogate the white supremacist, patriarchal, and heteronormative lens from which I learned about slavery.

The site visits also complicated my classmates' beliefs. Each student approached their international experience with a slew of ideas and knowledge developed from academics, social interactions, inequities, politics, and the media. For example, when asked, "What did your reaction to leaving your friends and family reveal about yourself?" one student noted, "It reveled [sic] that I should not believe every stereotype out there, because in most cases they are incorrect. The stereotypes about Africa as a whole do not do a justice for each country in Africa." (36) Visiting the dungeons, and digesting the atrocities that occurred at the sites, offered an accurate historical basis to reconsider previously held beliefs about African countries' histories and European incursions in Africa. Furthermore, both slave dungeons served as a painful reminder that people of African ancestry are still socially, politically, and economically suffering following the slave trade.

The visits to both dungeons offered an emotionally significant way of beginning to understand the ramifications of the slave trade in current race-based tensions, and the racially-based trauma associated with the Transatlantic Slave Trade. Another student noted the complex link between current race relations and the European facilitation of the Transatlantic Slave Trade:

Having taken this course, it now comes straight to mind anytime I think or hear of racial relations in America. The biggest takeaway for me was how deeply American culture is influenced by pre-colonial Africa. (37)

As my peer stated, pre-colonial African history and American history are deeply intertwined. The visits to the dungeons unearthed a range of emotions and responses from each student based on their identity, prior knowledge, and past experiences. For many white students, the historical site experiences were the first time they grappled with their privilege. However, very few white students interrogated their active role within present-day white supremacy. Few white students also acknowledged the violence in remaining unaware of the influence of precolonial African culture and the impact of the Transatlantic Slave Trade until being confronted by a slave dungeon. In contrast, for my Black peers and me, we carry the weight of the Transatlantic Slave Trade daily through the violence of intergenerational trauma. The dungeons complicated our understanding of our history and prompted us to reconnect deeply with our ancestry. My Black peers' and my visits to the dungeons were painful and visceral in a profoundly different way than those of our white counterparts, who viewed the dungeons from a historically and presently privileged position.

To further contextualize the topics addressed in the Precolonial African History course, our class visited Assin Manso. Assin Manso, commonly known as the home of the ancestral slave river, is where enslaved people took their last bath before their final voyage across the Atlantic Ocean and into permanent bondage. Our visit to Assin Manso, similarly to Cape Coast Dungeon and Elmina Dungeon, prompted a range of emotions, including loss and grief, but unlike the dungeons, concluded with a sense of spiritual reconnection. Arriving at Assin Manso moved me emotionally. As I entered Assin Manso, I felt the spirit of the area and the traumas, horrors, and resilience the site held. The repeated walking back and forth from the river resulted in a permanent trail created by enslaved people.38 Our tour guide requested that visitors take off their shoes before walking on the sacred ground that enslaved people walked upon. Removing our shoes eliminated any physical barriers between the soles of our feet and the land, allowing Africans of the diaspora to spiritually reconnect with their lost ancestors.

For white students, removing their shoes demonstrated solidarity and respect for the deceased. Everyone in the group proceeded to take off their shoes, except for a few white students. Although their decision, as one student stated, was to avoid the discomfort of walking barefoot on the trail, prioritizing their comfort over standing in solidarity with their Black peers and the deceased, it revealed their lack of understanding of their white ancestors' violence and the violence in their present decision. Their white ancestors, who facilitated the transport of slaves through Assin Manso and to the slave ports, elevated their desires over the respect and humanity of African people. Similarly, the white students who refused to remove their shoes prioritized their wishes over their Black peers. Their behavior stemmed from ancestral violence and a current understanding, through constant messaging from white supremacist systems, that their comfort surpasses the humanity of Black people. Their actions were a cruel reminder that their current privilege and the historical violence of the Transatlantic Slave Trade are deeply intertwined, and made it incredibly difficult for my Black peers and me to share in the historical site experiences alongside our white peers. 
Following my classmates' refusal to remove their shoes while walking the path, I chose to distance myself from my frustration toward their behavior and walked closer to my Black peers. By walking closely with my Black peers, I felt supported and validated. Although our experiences were different, we all situated ourselves within the African diaspora and, as a result, each deeply felt the pain and frustration stemming from our white peer's actions. There was unity in our closeness, which helped carry us through the path despite the emotional difficulty of being in Assin Manso while concurrently processing our white peers' actions.

As I walked behind my Black peers and looked down, I immediately noticed our feet stepping in unison along the trail, similar to our ancestors who walked Assin Manso's path decades before that moment. At the end of the path, I engaged in a ritual that allowed me to step into the river, speak with my ancestors, and feel their presence. For the first time in my life, I felt at peace with my position within the African diaspora. Assin Manso offered a safe harbor to transform my frustration and pursuits of a broken familial lineage into a step toward transformative healing and spiritual reconnection.

\section{The impact of slavery was a social, political, and economic inheritance passed through each of our families and the families of most people with African heritage.}

More than a brief insight into the horrors of slavery, for African Americans, visiting the locations offered reconnection, healing, and an unsettling awareness of the injurious and inhumane treatment of our family members. The visits also reminded us of our broken history and the continued mistreatment of people with African ancestry. My African American peers and I, before our experience in Ghana, traversed a multitude of racially-based traumas due to the Transatlantic Slave Trade. The impact of slavery was a social, political, and economic inheritance passed through each of our families and the families of most people with African heritage. For the aforementioned reasons, speaking with my white peers about our collective experience in the dungeons was difficult without considering their inability to personally and intimately understand the gravity of slavery, and the detrimental impact slavery continues to have in the lives of people with African heritage.

In between visits to Ghana's historical sites, I attended a class that contextualized the impact of the Transatlantic Slave Trade domestically and internationally, detailed the differences between indigenous Ghanaian slavery and chattel slavery, and offered a space for a diverse group of students to listen to each other's experiences. During the Pre-colonial African History course, each student could discuss their experiences at the historical sites and how the locations impacted them individually and collectively, given the intersections of the group's identities. We dissected the academic material and engaged in student-facilitated discussions about the topics addressed in our readings. The classes were an integral component of my experience in Ghana because I, along with my peers, analyzed and critically reflected on our visits to the historical sites.

Our conversations concerning race relations and slavery offered students of color a space to express emotional vulnerability and white students an opportunity to critically reflect on their role within oppressive systems. However, some white students centered themselves within conversations about Black experiences or resisted the conversation altogether, thereby suppressing the voices, histories, and struggles of Black students.

During one of our class discussions about our experiences at Assin Manso, my Black peers and I addressed the white students in the room who had refused to remove their shoes as they walked along Assin Manso's path. In response to being asked about the offensive behavior, one student expressed that he did not intentionally offend anyone and likened his experience visiting Auschwitz to the experience of Black Americans visiting the slave dungeons. He explained that he treated Auschwitz as sacred ground and, similarly, treated Assin Manso as sacred. The other white student who refused to take off their shoes at the site echoed the sentiments of the student discussing his experience at Auschwitz. Although this student was attempting to rectify the situation, he did so by mistakenly likening his own experience at Auschwitz and the experience of Black Americans. He centered his whiteness in a conversation about Black experiences and, rather than immediately apologize for his actions, provided various justifications for his actions. He apologized after being provided with several reasons from many students in the class regarding why his actions were offensive regardless of his intention. The conversation left my Black peers and me experiencing familiar feelings of frustration toward the student's failure to take responsibility for his actions. His actions spoke to a larger pattern of white people routinely centering themselves within Black experiences and, through their behavior, disregarding the harm caused by historical injustices perpetrated by white people.

Some white students used the classroom discussions as an opportunity to listen to the struggles of their Black peers and develop new ways of understanding their histories and the history of the Transatlantic Slave Trade while acknowledging white supremacist systems. Other students used the classroom discussions to create space for Black students to process the difficult experiences at the historical sites.

My peers' comments demonstrate the critical role of diversity in any educational course, point to the demographic void commonly found in academic spaces, and reaffirm that simply reading from a textbook does not always suffice. The topic of slavery necessitates an open conversation about the effect of slavery, with the most impacted demographics present-descendants from the African diaspora. The experiential course offered a unique opportunity to physically engage with the academic material through historical sites and participate in dialogue about the institution of slavery, how it persists today, and the impact of white supremacy both in the classroom and at the historical sites. 
The classroom discussions also allowed me and my African American peers to ask other students about any behavior regarded as offensive at the historical sites. For the first time, my opinion regarding the historical and present impact of racism in a predominately white classroom did not feel inconsequential. Furthermore, the professor's facilitation of inclusive conversations throughout the course prepared students for future intercultural interactions and prompted students to interrogate their role within hierarchical systems of oppression.

The classroom demographic fostered an environment conducive for nuanced discussions about racism, the enslavement methods employed by European colonial powers, the massive depopulating of Africa, and the altered development and political trajectory of various African countries. During class, students discussed their life experiences, the intersections of their identities, and the privilege they possess. The moments of self-reflection allowed many students to meaningfully interrogate their position within existing hierarchies. For some white students, their experience in Ghana was the first time their privilege was elucidated by minority students who are negatively and disproportionately impacted by white privilege.

The experiential learning course was also meaningful because a professor of color taught the students about the institution of slavery. The presence of a professor of color, of African American and Mexican American heritage, provided white students with a unique and important perspective regarding the plight of people with African heritage. White students studied the pervasive effects of racism today and the historical justifications for enslaving an entire population and witnessed a professor defying racial stereotypes as they read the literature. John King, the Secretary of Education, expressed that "white students. . . can benefit by viewing people of color in positions of power that they trust and respect and grow to love." (39) The white students developed a bond with the professor and, consequently, felt comfortable enough to speak about racial inequality and how they can work to deconstruct white supremacist systems.

The presence of a professor of color served a critical role in challenging and confronting baseless, racist notions informed by white supremacy that persist today. Our professor's presence also improved marginalized students', and specifically African American students', classroom experience. For students of color, the classroom discussions demonstrated moments of racial solidarity through the decentering of white voices. Additionally, witnessing our professor encourage mutual accountability, welcome emotional vulnerability, and emphasize a diversity of perspectives created a space for Black students to be emotionally transparent and open, which professors do not commonly facilitate in academic settings. Josh Moss claims that, "minority teachers. . . provide culturally relevant teaching, develop trusting relationships with students, confront issues of racism through teaching, and become advocates and cultural brokers." (40)

Professors of color become advocates for students, and particularly marginalized students, in the classroom. Our professor was an advocate and liaison between Black, white, and other students of color to address racial and cultural differences while honoring intersectional and inclusive practices. Furthermore, the presence of a professor of color reminded students of color that their classroom contributions and dialogue were valued, uplifting, and understood. Although the discussions were emotionally trying, the conversations were integral in engaging with our readings and historical events. The students' and the professor's diverse backgrounds allowed students to participate in social responsibility, embrace their identities, and gain deeper access to their humanity. Furthermore, experience in Ghana reminded me that I am a part of the African diaspora and, consequently, will always be deeply connected to my African heritage despite the generational trauma and loss perpetuated by slavery.

\section{Conclusion}

Educators have a moral obligation to not only decenter white dominant discourse in the classroom, but to ensure that pedagogical approaches highlight anti-racist discourse as a way to shed light on historical and current-day practices that uphold white supremacy. I argue that introducing antiracist pedagogy to students prior to embarking on study abroad trips located in the Africa may eliminate intentional and unintentional microaggressions and disrespectful behaviors. In addition, offering courses on CRT that map how racist practices and racism developed in the U.S. and globally would serve to dismantle white supremacy ideologies. In this way, students can begin an educational trajectory that better prepares them for study abroad programs. Issac Carter argues that, "Higher education shares a colonial history with slavery, and despite a lack of scholarship or teaching on this position, the Academy is an equally peculiar institution ..." (41) Let us not allow the Academy to be a peculiar institution where white supremacy is left unchallenged and Black voices are silenced.

\section{Notes}

1. The program was split into two courses; the four-week study program spent two weeks on each.

2. The study abroad course, entitled "Pre-colonial Africa," offers a history of pre-colonial Ghana, mainly with regard to various forms of slavery and the global development of Human Rights law. From indigenous slavery to the transatlantic slave trade, we will explore the various ways in which people inhabited subordinate statuses within African societies.

3. Gary Dorrien, "Achieving the Black Social Gospel, " Breaking White Supremacy: Martin Luther King Jr. and the Black Social Gospel (New Haven, CT: Yale University Press, 2018), 1.

4. Ibram X. Kendi, How to be an Antiracist (New York: Random House, 2019), 101. 
5. Angela Davis, June 9, 1972, http://americanradioworks.publicradio.org/features/blacks peech/adavis.html.

6. See Kimberlé Crenshaw, et al. Critical Race Theory: The Key Writings That Formed the Movement (New York: W.W. Norton \& Co., 1995); Khiara M. Bridges, Critical Race Theory: A Primer (St. Paul, MN: 2019)

7. George J. Sefa Dei, "Reframing Critical Anti-Racist Theory (CART) for Contemporary Times," Contemporary Issues in the Sociology of Race and Ethnicity:A Critical Reader (Counterpoints), 445.

8. Miriyam Aouragh, "'White privilege' and shortcuts to antiracism," Race and Class, 61, no. 4.

9. Benjamin P. Bowser, "Racism: Origin and Theory," Journal of Black Studies, 8, no. 6 (September 2017): 574.

10. Anonymous student comment, Ghana Study Abroad Refection, November 2019.

11. A South Asian student of color might be contending with their internalized anti-Blackness, a budding or growing awareness of their criminalization as a real or perceived Muslim, and the ways in which the racist "model minority" myth shapes their lived experience.

12. Tori DeAngelis, "In search of cultural competence," Monitor on Psychology, 46, no. 3 (March 2015): 64; Miu Chung Yan, "How Cultural Awareness Works; An Empirical Examination of the Interaction between Social Workers and their Clients," Canadian Social Work Review, 22, no. 1 (2005): 6.

13. Eduardo Bonilla-Silva, Racism without Racists: ColorBlind Racism and the Persistence of Racial Inequality in America (Lanham, MD: Rowman \& Littlefield Publishers, 2017), 7.

14. See Curtis Kleim and Carolyn Somerville, Mistaking Africa: Curiosities and Inventions of the American Mind (Routledge, 2017).

15. Muhammed Musa, "Technology and the Democratic Space in Africa: A Re-examination of the Notion of the Digital Divide," In Mapping the Digital Divide in Africa, eds. Bruce Mutsvairo and Massimo Ragnedda (Amsterdam University Press, 2019), 66-67.

16. Henning Pözold, Learning and Teaching in Adult Education: Contemporary Theories (Opladen and Farming Hills, MI: Barbara Budrich Publishers, 2011), 50.

17. John Dewey, Democracy and Education: An Introduction to the Philosophy of Education (New York: Macmillan Co., 1922), 63.

18. Anonymous student response, Student Evaluation Survey, Duquesne University, Summer 2019.

19. Anonymous student response, Student Evaluation Survey, Duquesne University, Summer 2019.

20. Anonymous student comment, Ghana Study Abroad Reflection, November 2019.

21. Anonymous student comment, Ghana Study Abroad Reflection, November 2019.
22. Anonymous student comment, Ghana Study Abroad Reflection, November 2019.

23. Daniel Paracka, "The Kalamazoo/Fourah Bay College Partnership: A Context for Understanding Study Abroad in Africa," in Teaching Africa, eds. Brandon Lundy and Solomon Negash (Bloomington, IN: University of Indiana Press, 2013), 207.

24. Trevor R. Getz, Abina and the Important Men (Oxford: Oxford University Press, 2015).

25. Moses, 63.

26. Anonymous student comment, Ghana Study Abroad Reflection, November 2019.

27. Anonymous student comment, Ghana Study Abroad Reflection, November 2019.

28. Anonymous student comment, Ghana Study Abroad Reflection, November 2019.

29. Anonymous student comment, Ghana Study Abroad Reflection, November 2019.

30. Jorge Cubillos and Thomas Ilvento, Intercultural Contact in Short-term Study Abroad Programs, Hispania, Vol. 101, no. 2 (June 2018): 251.

31. Neriko Musha Doerr, "Falling In/Out of Love with Place: Affective Investment, Perceptions of Difference, and Learning in Study Abroad," in The Romance of Crossing Borders: Studying and Volunteering Abroad (New York: Berghahn Books, 2017), 144 ..

32. A. Doris Banks Henries, "Black African Cultural Identity," Présence Africaine, Negro-African Cultural Identity, Vol. 3, (1977): 121.

33. Martin R. Delany, Blake or; The Huts of America (Beacon Press, 1971); Robert Steven Levine, Martin R. Delany: A Documentary Reader; David Levering Lewis, W.E.B. Du Bois: A Biography (New York: Holt Paperbacks, 2009); W.E.B. Du Bois, The Souls of Black Folk (New York: Dover Publications, 1994); Herbert Berg, Elijah Muhammad and Islam (New York: New York University Press, 2009); Booker T. Washington, Up From Slavery (Independently Published, Gianluca, 2017); Malcom X, By Any Means Necessary (New York: Pathfinder Press, 1992).

34. Bryan Hill, "Elmina Castle and its Dark History of Enslavement, Torture, and Death," Ancient Origins (July 2018), https://www.ancient-origins.net/ancient-placesafrica/elmina-castle-and-its-dark-history-enslavementtorture-and-death-003450, 1, accessed date 13 May 2020.

35. "The History of Cape Coast Castle" (Cape Coast Castle Museum, Ghana West Africa), https://www.ancientorigins.net/ancient-places-africa/elmina-castle-and-itsdark-history-enslavement-torture-and-death-003450, 1 , accessed date 13 May 2020.

36. Anonymous student comment, Ghana Study Abroad Reflection, November 2019.

37. Anonymous student comment, Ghana Study Abroad Reflection, November 2019.

\section{RADICALTEACHER}

http://radicalteacher.library.pitt.edu
No. 121 (Winter 2021)

DOI $10.5195 /$ rt. 2021.898 
38. "Assin Manso Slave Market," Ghana Tourism Authority (Internet

Archive),

https://web.archive.org/web/20140714181444/http://ww

w.ghana.travel/touring_ghana/historic_sites/assin_manso_ slave_market/, 1, accessed date 13 May 2020.

39. Josh Moss, "Where Are All the Teachers of Color?," Harvard Ed. Magazine (Harvard Graduate School of Education, 2016),

https://www.gse.harvard.edu/news/ed/16/05/where-areall-teachers-color, 1, accessed date 13 May 2020.

40. Moss, "Where Are All the Teachers of Color?."

41. Issac Carter, "Counter-Narratives as Critical Invitations for Change: Race-Centered Policy-Making and Backlash at a Peculiar Institution," Whiteness, Power, and Resisting Change in US Higher Education, edited by Kenneth R. Roth and Zachary Ritter (London: Palgrave Macmillan, 2021), 54. 